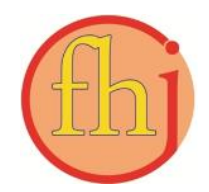

Faletehan Health Journal, 7 (2) (2020) 104-112

www. journal.Ippm-stikesfa.ac.id/ojs/index.php/FHJ

ISSN 2088-673X | e-ISSN 2597-8667

\title{
Pengaruh Terapi Bacaan Al-Qur'an (TBQ) sebagai Biblioterapi Islami pada Kesehatan Mental Narapidana Lesbian
}

\author{
Inggriane Puspita Dewi ${ }^{1}$, Redita Aida Suryadi ${ }^{1}$, Siti Ulfah Rifa'atul Fitri ${ }^{2}$ \\ ${ }^{1}$ Sekolah Tinggi Ilmu Kesehatan 'Aisyiyah Bandung \\ ${ }^{2}$ Universitas Padjadjaran Bandung \\ *Corresponding Author: ine.stikes12@gmail.com
}

\begin{abstract}
Abstrak
Kapasitas rutan dan lapas di Jawa Barat saat ini mengalami kelebihan sampai dengan $52 \%$, salah satu dampak yang terjadi adalah penyimpangan perilaku seksual. Penyimpangan perilaku seksual dapat disebabkan oleh buruknya kesehatan mental seorang narapidana. Penggunaan Terapi Bacaan al-Qur'an (TBQ) sebagai intervensi untuk kesehatan mental belum dilakukan pada kelompok lesbian ini. Penelitian ini untuk mengetahui adanya pengaruh Terapi Bacaan alQur'an (TBQ) sebagai biblioterapi Islami pada kesehatan mental narapidana wanita yang mengalami penyimpangan orientasi seksual (lesbian). Penelitian kuantitatif dengan quasi eksperimen time series design. Sample penelitian ini adalah 22 responden. Responden diberikan kuisioner Mental Health Inventory, kemudian diberikan intervensi: 1) sesi membaca Al-Quran dan 2) membaca Biblioterapi Islami sebanyak 1 kali setiap hari Jum'at selama tiga pekan berturutturut dengan tema yang berbeda-beda. Analisis bivariate yang digunakan adalah uji repetead Anova. Terdapat pengaruh pemberian Terapi Bacaan al-Qur'an (TBQ) sebagai biblioterapi Islami pada peningkatan kesehatan mental $(p<0,001)$. Biblioterapi Islami ini mendorong responden menyadari fitrahnya sebagai perempuan, mengenal penciptanya serta kewajiban terhadap pencipta-Nya. Terapi Bacaan al-Qur'an (TBQ) sebagai biblioterapi Islami dapat menjadi salah satu pilihan intervensi spiritual untuk kelompok wanita lesbian yang beragama Islam dalam meningkatkan kesehatan mentalnya.
\end{abstract}

Kata Kunci: Biblioterapi Islami, Kesehatan Mental, Lesbian

\section{The Effects of Al-Qur'an Reading Therapy as Islamic Bibliotherapy on Mental Health of Lesbian Prisoner}

\begin{abstract}
The capacity of detention and prisons in Jawa Barat currently has an excess of up to 52\%, one of the impacts that occur is sexual behavior distortion. Deviations in sexual behavior can be caused by low mental of inmates. The use of Islamic bibliotherapy as an intervention for mental health has not been done in this lesbian group. The purpose of this study to find out the effect of Islamic bibliotherapy on mental health of female prisoners who experience sexual orientation deviations (lesbian). Quantitative research with quasi-time series design experiments. The sample of this study was 22 respondents. Respondents were given a Mental Health Inventory, then were given interventions: 1) Al-Quran reading session and 2) reading Islamic bibliotherapy one time every Friday for three consecutive weeks with different themes. The bivariate analysis in mental health used the Repeated Measures Anova. There is an effect of Islamic bibliotherapy therapy mental health $(p=0.001)$. Islamic bibliotherapy can be an option for spiritual intervention for a group of lesbians to improve their mental health.
\end{abstract}

Keywords: Islamic Bibliotherapy, Mental Health, Lesbians 
Faletehan Health Journal, 7 (2) (2020) 104-112

\section{Pendahuluan}

Setiap orang memiliki kecenderungan seksual yang berbeda-beda baik heteroseksual, homoseksual mapun biseksual. Masing-masing orientasi tersebut terbentuk akibat dari berbagai faktor yang terjadi pada setiap individu seperti perkembangan genetik dan hormon selama proses prenatal (Bjarnadottir, 2016), keadaan sosial dan budaya tempat individu tumbuh dan berkembang (Purvis, 2017).

Lembaga pemasyarakatan atau LAPAS menjadi salah satu area yang beresiko terhadap perkembangan penyimpangan orientasi seksual. Total kapasitas ideal lapas dan rutan di Jawa Barat adalah 15.658 warga binaan, namun kenyataanya jumlah melebihi kapasitas ideal yaitu 23.681 warga binaan (Sugiyarto, 2019). Studi pendahuluan menunjukan jumlah narapidana di Kota Bandung sebanyak 2.892 orang. Jumlah tersebut terdiri atas Lapas Sukamiskin dengan jumlah 520 orang, Lapas Banceuy 520 orang (Tiah \& Herdiana, 2019), Lapas Narkotika 1.268 orang, Lapas Perempuan 447 orang, dan Lapas Anak 159 orang. Kapasitas rutan dan lapas di Jawa Barat saat ini mengalami kelebihan sampai dengan $52 \%$ (Aminah, 2019).

Salah satu dampak yang terjadi akibat kondisi diatas adalah penyimpangan perilaku seksual (Sugiyarto, 2019). Penyebab lain dari peyimpangan perilaku seksual di lapas adalah sulit menahan hasrat seksual (Lestari \& Evi, 2012) dan lama masa tahanan (Gunawati, Abdul \& Idawati, 2017). Di Lapas perempuan belum ada intervensi khusus tentang pembinaan bagi kelompok lesbian. Perilaku orientasi seksual berupa homoseksual di kalangan wanita atau biasa disebut sebagai lesbian memiliki berbagai dampak dalam pemenuhan kebutuhan lainnya karena mereka berada dalam kondisi tekanan dan stigma yang muncul dari lingkungan. Beberapa dampak yang muncul dikalangan homoseksual ini bisa meliputi aspek fisik, emosional, sosial, dan spiritual.

Masalah juga timbul dari dalam diri narapidana seperti kehilangan peran, ketakutan menjalani rezim penjara, kehilangan identitas yang terhormat, serta ketakutan meninggal di dalam penjara. Aspek spiritualitas di kalangan homoseksual umumnya merupakan area yang tidak terkaji (Chew Sim Chee, Noor, \& Ahmad, 2013). Bahkan spiritual cenderung dekat dengan aspek religiusitas namun beberapa penelitian menemukan bahwa aspek spiritual menjadi sumber konflik bagi para homoseksual untuk bisa berdamai antara keyakinan dan perilaku seksual yang mereka lakukan (Corrigan et al., 2009).

Hasil penelitian lain menunjukan para homoseksual mengalami internal konflik berkaitan dengan tingkat spiritual mereka dalam menghadapi berbagai tekanan yang muncul dari luar yang diekspresikan ke dalam bentuk depresi, merasa bersalah, keinginan untuk bunuh diri, dan mengasingkan diri (Kusuma \& Surakarta, 2012). Padahal, spiritual merupakan salah satu bentuk pertahanan diri dan perlindungan kesehatan dalam lingkungan umum dan sangat berpengaruh terhadap kesejahteraan spiritual dan kesehatan mental di kalangan homoseksual.

Konflik batin yang diekspresikan ke dalam bentuk depresi, merasa bersalah, seperti diuraikan sebelumnya, serta kepuasan hidup berkorelasi dengan kesejahteraan spiritual seseorang (Dadfar, Bahrami, Noghabi, \& Askari, 2016; Shafi, Bashir, Yousuf, Parveen, \& Akhter, 2016). Intervensi spiritual sebaiknya digunakan untuk mengatasi masalah psikologis (Alorani \& Alradaydeh, 2019). Biblioterapi Islami telah dicoba sebagai intervensi spiritual pada beberapa masalah psikologis, seperti menurunkan tingkat kecemasan pada ibu pre operasi sectio sesaria (Fitriyani \& Dewi, 2017), meningkatkan koping religius pasien hemodialisis (Dewi \& Widiyanti, 2018), namun belum ada penelitian mengenai efek biblioterapi Islami terhadap kesejahteraan spiritual dan kesehatan mental pada wanita narapidana dengan homoseksual atau lesbian.

Kesehatan mental dalam Islam memandang motivasi spiritual seperti Ihsan (kesempurnaan), Ikhlas (ketulusan), dan Amanah (kepercayaan). Ihsan mengacu pada Allah SWT, yang mengetahui aktivitas setiap individu; Ikhlas merujuk pada melakukan segala sesuatu yang menginginkan keridhaan Allah SWT. Amanah mengacu pada tanggung jawab moral untuk memenuhi kewajiban hanya untuk menginginkan berkah Allah SWT. Amanah mengungkapkan moralitas sosial dapat membuat hidup manusia lebih bermakna karena mengandung nilai-nilai integritas, tanggung jawab, kejujuran, transparansi, dan akuntabilitas. Spiritualitas dalam Islam memastikan bahwa semua aktivitas kehidupan mengarah pada keridhaan Allah SWT. Semangat Islam adalah perwakilan dari semua urusan batin umat manusia, 
yang akhirnya menghubungkan dirinya dengan Penciptanya (Al-Banna, 2016).

Jika karakteristik menjadi orang baik sesuai dengan nilai-nilai Alquran tercapai, maka seseorang akan mengalami kesehatan mental yang baik (Apiep, 2016). Tanda-tanda bahwa orang yang sehat secara mental adalah sebagai berikut: (1) mencapai kepuasan hidup dengan perasaan bahagia, (2) Efisien dalam memenuhi kebutuhan mereka, (3) terhindar dari kecemasan, (4) terbebas dari perasaan bersalah, (5) tugas perkembangan sesuai usia, (6) Mampu beradaptasi dengan lingkungan mereka, (7) Memiliki otonomi, dan harga diri, (8) Mampu membangun hubungan emosional dengan orang lain, dan (9) dapat menerima kenyataan. Maka membangun kesehatan mental yang ideal bagi seorang muslim/muslimah adalah merujuk kepada nilai-nilai Al-Qur'an.

Al-Qur'an membimbing umatnya untuk tetap berada di jalan yang lurus, jujur, beribadah dan memulihkan jiwa, dengan mengikuti petunjuk AlQur'an maka alam akan kembali ke kualitas manusia yang sempurna, menumbuhkan kasih sayang di antara manusia, tulus, terima kasih dan sabar. Al-Qur'an memuat bacaan-bacaan yang penuh hikmah melalui kisah maupun perintah dan larangan (Inggriane, 2016). Al-qur'an memiliki fungsi sebagai syifa (penyembuh) disebutkan dalam surat Al-Isra ayat 82 , maka membaca alQur'an dapat memberikan efek terapi bagi pembacanya. Cohen (1988) mengatakan terapi melalui bacaan dikenal dengan istilah biblioterapi.

Biblioterapi digunakan karena merupakan salah satu terapi kognitif dan perilaku (Cognitive Behavioral Therapy atau CBT) memiliki beberapa keuntungan yaitu hasil yang efektif, hemat biaya, kontak yang minimal dengan petugas kesehatan atau konselor, karena terapi melalui membaca sebagai cara untuk menolong diri sendiri secara mandiri (Pardini et al., 2014). Biblioterapi efektif dalam mengurangi gejala depresi orang dewasa dalam periode jangka panjang, memberikan pengobatan yang cepat dan terjangkau sehingga dapat mengurangi obat lebih lanjut. Hasil tinjauan ini menunjukkan bahwa biblioterapi dapat memainkan peran penting dalam pengobatan masalah kesehatan mental yang serius (Frieswijk, Steverink, Buunk, \& Slaets, 2006; Gualano et al., 2017).

Melihat fenomena tersebut, komunitas homoseksual khususnya yang berada di Lapas narapidana wanita merupakan kelompok yang beresiko akan mengalami kehilangan dan kesehatan mental, bila dibiarkan maka akan berdampak kualitas hidup mereka. Penelitian ini memiliki tujuan membuktikan adanya pengaruh Biblioterapi Islami untuk kesehatan mental di kalangan kelompok lesbian. Penelitian ini diharapkan memberikan sumbangsih bagi intervensi keperawatan yang dapat membantu permasalahan spiritual dan mental kelompok beresiko yaitu lesbian.

\section{Metode Penelitian}

Metode yang digunakan adalah metode quasi eksperimen time series design. Dalam desain ini kelompok yang digunakan untuk penelitian, hanya kelompok perlakuan tanpa kelompok kontrol dan dipilih secara non random (Sugiyono, 2013). Populasi dalam penelitin ini berjumlah 94 narapidana perempuan dengan kategori Homoseksual menurut Kinsey Skala 1 sampai 5. Penelitian ini merupakan penelitian analitis numerik berpasangan kuantitatif sehingga penghitungan jumlah sampel penelitian ini berdasarkan penelitian sebelumnya yang dilakukan oleh Dewi dan Widiyanti (2018), mengenai pemberian qur'anic therapy sebagai biblioterapi Islami untuk peningkatan koping religius pasien hemodialisis didapatkan standar deviasi 6,034 dan perbedaan mean 3,7; sehingga sampel penelitian ini berjumlah 22 orang dan pengambilan sampel secara purposive sampling. Sampel dipilih berdasarkan kriteria inklusi yang meliputi kategori lesbian dari hasil kuesioner Kinsy dengan skala 5, beragama Islam, usia dewasa $\geq 19$ tahun. Adapun kriteria eksklusi meliputi wanita lesbian penghuni lapas dengan keterbatasan komunikasi, dan wanita lesbian memiliki gangguan mental dan kognitif. Kriteria drop out yaitu responden tidak menuntaskan intervensi dan mengisi kuisioner tidak lengkap.

Instrumen untuk mengukur kesehatan mental adalah Mental Health Inventory (HMI). Awalnya dikembangkan oleh Veit dan Ware (1983), di lakukan penyesuaian oleh peneliti, kemudian dilakukan uji validitas ulang pada 30 orang narapidana dengan lesbian, diperoleh hasil koefisien alpha cronbach 0,957. Kuesioner Kesehatan Mental, terdiri dari 15 pernyataan, dengan kategori kesehatan mental yang baik ( $\geq 61$ 90), cukup $(30-<61)$ dan kategori kurang (<30).Peneliti memilih menggunakan HMI karena HMI merupakan skala ukur yang sering digunakan 
Faletehan Health Journal, 7 (2) (2020) 104-112

www. journal.Ippm-stikesfa.ac.id/ojs/index.php/FHJ

ISSN 2088-673X | 2597-8667

dan sudah mencakup dua dimensi yaitu tekanan psikologis yang terdiri atas kecemasan, kehilangan kontrol perilaku/emosional, dan depresi sementara dimensi psikologis terdiri atas subskala kepuasan hidup, ikatan emosional dan pengaruh positif pada lingkungan (Pandya, 2018). Adapun Terapi Bacaan al-Qur'an (TBQ) sebagai biblioterapi Islami pada penelitia ini memiliki tema:

1. Mengenal diri, tema bacaan ini memiliki tujuan memberikan pesan tentang identitas diri sebagai sebaik-baik makhluk ciptaan Tuhan, memberi ruang kesadaran tentang hakikat dirinya sebagai perempuan serta tujuan hidup yang selayaknya dicapai oleh seorang muslimah.

2. Allah Ta'ala sebagai pemberi kehidupan, tema bacaan ini memiliki tujuan untuk memberikan kekuatan keyakinan, bahwa Allah ta'ala maha pemberi nikmat, maha pengampun dan penyayang pada hamba-Nya, sehingga setiap beban yang dihadapi, akan terasa ringan dibandingkan kenikmatan dari Allah Ta'ala yang jauh lebih besar.

3. Ibadah sebagai penyembuh, tema ketiga memberikan harapan bahwa setiap hamba yang memiliki permasalahan hidup kemudian menjadi cemas bahkan depresi, dapat diatasi dengan mendekatkan diri kepada Allah Ta'ala melalui proses taubat dan ibadah kepada-Nya secara rutin walaupun sedikit - sedikit (bertahap).

Setelah itu, data diproses melalui pengeditan, pengkodean, dan memasukkan menggunakan program komputer. Peneliti melakukan analisis univariat untuk data demografis serta skor rata-rata pretest dan posttest untuk variabel kesehatan mental. Kemudian kami melakukan analisis bivariat menggunakan uji Repeated Anova untuk mengklarifikasi signifikansi perbedaan dalam ratarata skor pretest dan posttest. Pemberi terapi pada penelitian ini adalah peneliti, dan asisten peneliti mengobservasi proses pemberian terapi serta memberikan kuisioner Mental Health Inventory (HMI) sebelum dan setelah pemberian intervensi.

\section{Hasil dan Pembahasan \\ Karakteristik responden}

Responden dalam penelitian ini, kisaran usia 21-39 tahun (87\%), dengan usia rata-rata 27 tahun, untuk kategori status perkawinan menunjukkan status responden terbanyak adalah lajang (60\%). Tingkat pendidikan tertinggi responden adalah sekolah menengah (50\%), dan untuk kategori lama tahanan narapidana dalam kisaran 3-5 tahun $(36,4 \%)$, dan dengan rata-rata lama di tahanan 4 tahun 8 bulan.

Tabel 1. Karakteristik responden $(\mathrm{n}=22)$

\begin{tabular}{lccc}
\hline Karakteristik & N(\%) & mean & SD \\
\hline Usia (tahun) & & & \\
$21-39$ tahun & $19(87)$ & 27 & 5,931 \\
40-59 tahun & $3(14)$ & & \\
\hline Status Marital & & & \\
Belum Menikah & $13(60)$ & & \\
Menikah & $1(4)$ & & \\
Janda & $8(36)$ & & \\
\hline Tingkap & & & \\
Pendidikan & & & \\
SD & $1(5)$ & & \\
SMP & $8(36)$ & & \\
SMA & $11(50)$ & & \\
PT & $2(9)$ & & \\
\hline Lama Tahanan & & & \\
< 2 tahun & $5(23)$ & 4,8 & 2,364 \\
3-5 tahun & $8(36)$ & & \\
5-10 tahun & $7(32)$ & & \\
$>10$ tahun & $2(9)$ & & \\
\hline
\end{tabular}

\section{Deskripsi Skor kesehatan mental}

Kuesioner diberikan kepada responden sebelum pemberian Terapi Bacaan al-Qur'an (TBQ) sebagai biblioterapi Islami. Kemudian kesehatan mental diukur lagi setelah intervensi pertama, kedua dan ketiga dalam rentang waktu satu minggu setiap intervensi. Setelah setiap intervensi, responden diajak berdiskusi untuk menemukan makna teks yang mereka baca.

Data pada tabel 2. menunjukkan skor untuk kesehatan mental sebelum intervensi rata-rata 50,77 (kesehatan mental yang cukup) dan setelah intervensi pertama $(61,00)$, kedua $(64,00)$ dan ketiga $(68,50)$ kategori menjadi baik $(100 \%)$, karena skor menunjukkan angka 61 ke atas.

\section{Pengaruh biblioterapi Islami terhadap kesehatan mental wanita lesbian}

Uji normalitas menggunakan uji Shapiro Wilk, seperti yang ditunjukkan pada Tabel 3 .

Hasil data uji normalitas untuk kesehatan mental menunjukkan semua data normal, jadi analisis bivariat untuk efek Terapi Bacaan alQur'an (TBQ) sebagai biblioterapi Islami pada kesehatan mental menggunakan tes Repeated ANOVA. 
Tabel 2. Skor Kesehatan Mental Lesbian Sebelum dan Setelah Intervensi $(n=22)$

\begin{tabular}{cccccc}
\hline Kesehatan Mental & Mean & Median & SD & Min & Max \\
\hline Pre Intervensi & 50,77 & 52,50 & 10,15 & 25 & 68 \\
\hline Post Intervensi-1 & 61,32 & 61,00 & 11,93 & 35 & 83 \\
\hline Post Intervensi-2 & 64,14 & 64,00 & 12,22 & 40 & 88 \\
\hline Post Intervensi-3 & 68,41 & 68,50 & 10,57 & 48 & 89 \\
\hline
\end{tabular}

Table 3. Uji Normalitas Data

\begin{tabular}{ccc}
\hline Kesehatan Mental & $\boldsymbol{p}$ & Interpretation \\
\hline Pre Intervensi & 0,590 & normal \\
\hline Post Intervensi-1 & 0,754 & normal \\
\hline Post Intervensi-2 & 0,917 & normal \\
\hline Post Intervensi-3 & 0,897 & normal \\
\hline
\end{tabular}

Tabel 4. Pengaruh Biblioterapi pada Kesehatan Mental diantara Tahanan Wanita Lesbian $(\mathrm{n}=22)$

\begin{tabular}{|c|c|c|c|c|}
\hline Kesehatan Mental & Mean & SD & Test of Sphericity & p Value* \\
\hline Pre Intervensi & 50,77 & 10,15 & \multirow{4}{*}{0.000} & \multirow{4}{*}{$<0.001 * *$} \\
\hline Post Intervensi-1 & 61,32 & 11,93 & & \\
\hline Post Intervensi-2 & 64,14 & 12,22 & & \\
\hline Post Intervensi-3 & 68,41 & 10,57 & & \\
\hline
\end{tabular}

Data penelitian ini tidak memenuhi asumsi kemiripan varian berdasarkan nilai kebulatan $(0,000)$, nilai $\mathrm{P}$ mengacu pada nilai Greenhouse Geisser pada output tes efek antar subjek $(<0,001)$, sehingga ada perbedaan rata-rata pengukuran sebelum intervensi dan setelah intervensi, Dengan demikian, dapat disimpulkan bahwa intervensi Terapi Bacaan al-Qur'an (TBQ) sebagai biblioterapi Islami berpengaruh terhadap kesehatan mental.

Terapi Bacaan al-Qur'an (TBQ) sebagai biblioterapi Islami pada kesehatan mental di antara tahanan wanita lesbian ini menunjukkan pengaruh yang signifikan dalam meningkatkan kesehatan mental lesbian $(\mathrm{P}<0,001)$ untuk CI 0,5\%. Terapi bacaan Qur'an diawali dengan membaca qur'an surat At-Tin ayat 1 s.d 6, kemudian responden membaca hikmah surat At-Tin, yaitu kisah nabi Musa a.s, nabi Isa a.s dan nabi Muhammad SAW, sebagai sosok yang tangguh menghadapi cobaan hidup. Surat At-Tin juga menyampaikan hikmah tentang kesempurnaan manusia dilihat dari imannya, bukan rupa fisiknya. Tujuan dari tema ini adalah untuk memberikan kesadaran kepada lesbian, bahwa mereka adalah makhluk Allah yang paling sempurna dengan syarat mereka memenuhi komitmen terhadap iman dan perbuatan baik, bacaan ini juga menggambarkan langkah-langkah untuk menjadi manusia yang sempurna, seperti: menghindari kebodohan, mengendalikan keinginan dan menyadari pengaruh bisikan setan, sehingga mereka dapat mengendalikan perilaku.

Tema kedua adalah Allah SWT sebagai pusat kehidupan. Allah memperkenalkan dirinya dalam, "Allah, tidak ada Tuhan (yang memiliki hak untuk disembah), tetapi Dia yang hidup abadi terus merawat (makhluk-Nya); tidak mengantuk dan tidak tidur. Dia milik apa yang ada di surga dan di bumi. Tidak seorang pun dapat memberikan syahadat dengan Allah tanpa izin-Nya? Allah tahu apa yang ada di depan mereka dan di belakang mereka, dan mereka tidak tahu apa-apa dari pengetahuan Allah kecuali apa yang Dia inginkan. Kursi Tuhan menutupi langit dan bumi. Dan Allah tidak merasa berat mempertahankan keduanya, dan Allah Maha Tinggi dan Maha Besar "(Surat Al-Baqarah ayat 255). Dalam bacaan kedua ini, diselingi dengan kisah-kisah yang menceritakan tentang Allah yang Maha pengasih dan penyayang. Tema ini mengajak responden untuk kembali menyadari keberadaan Tuhan yang memberi kehidupan, mengurus setiap detail hidupnya, bahkan ketika seseorang mengalami kesedihan, kesulitan atau penderitaan, maka Tuhan berkata 
Faletehan Health Journal, 7 (2) (2020) 104-112

www. journal.Ippm-stikesfa.ac.id/ojs/index.php/FHJ

dalam "Siapa pun yang percaya kepada Allah pasti Dia akan menyediakan baginya jalan keluar. Dan berikan dia keberuntungan dari arah yang tidak terduga. "(Surat Ath Tholaq ayat 2-3), di sini solusi untuk masalah depresi dan kecemasan adalah dengan taqwa.

Tema berikutnya adalah upaya untuk menjadi orang yang lebih baik, bertaubat dari kesalahan yang dibuat, dan tidak putus asa dari rahmat Allah SWT. "Dan barangsiapa yang melakukan kejahatan dan menganiaya dirinya sendiri, maka ia memohon pengampunan dari Allah, pasti ia akan menemukan Allah, Maha Pengampun, Maha Penyayang." (Surat an-Nisa ayat 110). "Barangsiapa yang mengerjakan amal saleh, baik pria maupun wanita sementara dia seorang yang beriman, maka mereka masuk surga, dan mereka tidak dianiaya bahkan sedikitpun. "(Surat An-Nisa ayat 124)." Bahwa (yang telah kami perintahkan) adalah jalan lurus saya, maka ikutilah dia, dan jangan ikuti jalan (yang lain), karena mereka memisahkanmu dari jalan-jalan-Nya. Inilah yang Allah perintahkan agar kamu takuti. " Hal ini sesuai dengan yang dinyatakan Abdullah Gymnastiar bahwa, ada tiga hal yang dilakukan seseorang untuk menjadi hamba yang benar, yaitu selalu menjaga kebersihan hati, terbiasa dengan pertobatan, dan menjadi tulus dalam beribadah sesuai dengan sunnah Nabi Muhammad SAW, menjadi orang baik dapat membantu responden sadar untuk memberikan pengaruh positif bagi lingkungannya atau orang lain (Gymnastiar, 2018).

Peneliti menganalisis Terapi Bacaan alQur'an (TBQ) sebagai biblioterapi Islami ini berdampak pada peningkatan kesehatan mental lesbian, pertama, restrukturisasi kognitif dalam biblioterapi Islami mengarahkan responden untuk mengenali hubungan antara pikiran, emosi, dan perilaku, melalui deskripsi konsep mengetahui identitas seseorang sebagai wanita muslim, mengenal Allah Subhanallahu wa ta'ala sebagai pemberi kehidupan, beribadah sebagai penyembuhan dan kisah yang memiliki nilai hidup. Kedua, kerangka kerja TBQ pada penelitian ini dapat dilihat pada gambar 1:

Penelitian ini menggunakan biblioterapi kognitif berdasarkan nilai-nilai Islam, sehingga disebut Terapi Bacaan Qur'an (TBQ) sebagai biblioterapi Islami. Biblioterapi kognitif mengacu pada biblioterapi yang berbasis CBT (Cognitive Behavioral Therapy) memiliki isi tentang teori, perilaku, dan pendidikan psiko-spiritual untuk mengurangi dan menghilangkan beberapa jenis masalah spiritual dan mental tertentu (Andersson, 2009; Liu, E., Chen, W., Li, Y., Wang, C., Mok, T., \& Huang, 2009). Terapi bacaan qur'an dalam penelitian ini disusun melalui teknik didaktik dalam bentuk tulisan, yang mencakup tema kesehatan mental para lesbian. Al-Qur'an, sebagai panduan untuk kehidupan umat Islam, juga sebagai biblioterapi Islami, berisi bacaan yang memberikan efek terapi. Isi Al-Qur'an yang mengandung efek terapi: 1) memberikan informasi spiritual, 2) memberikan wawasan, 3) merangsang diskusi tentang masalah, 4) mengkomunikasikan nilai-nilai dan sikap baru, 5) menciptakan kesadaran bahwa orang lain memiliki masalah yang sama, 6) memberikan solusi yang realistis. Al-Qur'an membawa pesan monoteisme, hukum Islam yang sempurna, petunjuk tentang jalan lurus, sebagai Pengobatan (Syifa '), untuk penyakit tubuh dan jiwa. Ayat-ayat Al-Qur'an, memastikan bahwa AlQur'an adalah obat, "Dan Kami turunkan dari AlQur'an yang merupakan obat (Syifa) dan rahmat bagi mereka yang beriman dan Al-Qur'an tidak menambah pelaku kesalahan selain kerugian. " (alIsra' ayat 82).

Biblioterapi dapat digunakan oleh seseorang untuk menemukan solusi permasalahan yang sedang dihadapi melalui bacaan (Altunbay, 2018). Temuan penelitian mengenai pemanfaatan bacaan untuk keuntungan terapeutik atau dikenal dengan biblioterapi menunjukkan berbagai manfaat bagi pembaca mulai dari yang dinyatakan bebas dari kesepian dan isolasi hingga penurunan gejala depresi. Peneliti lain menemukan bahwa pembaca menunjukkan peningkatan kesadaran budaya, peningkatan koping religius, peningkatan pemahaman empatik, keterampilan pemecahan masalah yang lebih baik, dan keuntungan keseluruhan dalam meningkatkan wawasan (Bruneau \& Pehrsson, 2014; Dewi \& Widiyanti, 2018; Fitriyani \& Dewi, 2017; Pardini et al., 2014). Hasil ini menguatkan intervensi TBQ dapat membantu individu untuk menghargai diri mereka sendiri, menemukan cara untuk mengembangkan diri, dan menangani hal-hal sulit dengan cara yang lebih kreatif, terutama bagi individu yang mengalami gangguan emosi atau mental, dengan dilandasi oleh nilai-nilai Ilahiyah. 
Gambar 1. Kerangka kerja Terapi bacaan Qur'an

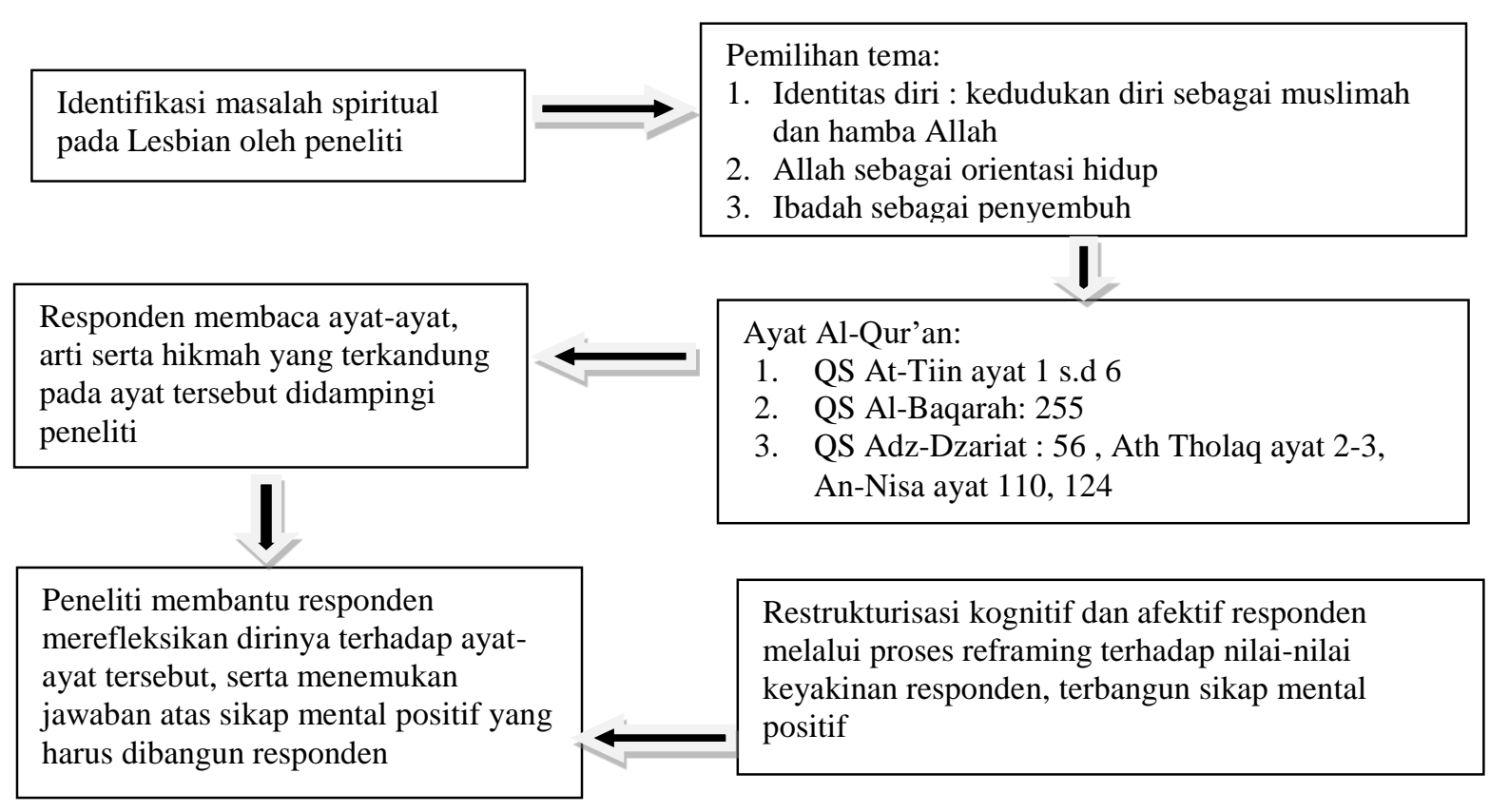

\section{Simpulan}

Kondisi mental yang sehat secara alami menuntun seseorang untuk menghindari pelanggaran etika moral yang berlaku di masyarakat, seperti penyimpangan orientasi seksual. Keterbatasan dalam penelitian ini adalah bahwa belum melakukan pengamatan jangka panjang dalam bentuk penelitian prospektif tentang efek TBQ pada perilaku penyimpangan seksual lesbian, tetapi dengan perubahan dalam skor ratarata kesehatan mental $(\mathrm{P}<0,001)$ menunjukkan ada pengaruh intervensi Terapi Bacaan Qur'an (TBQ) sebagai biblioterapi Islami pada kesehatan mental pada narapidana wanita dengan penyimpangan orientasi seksual (lesbian).

\section{Referensi}

Al-Banna. (2016). Journey Through The Qur'an. Bandung: Cordova.

Alorani, O. I., \& Alradaydeh, M. F. (2019). Depression, Aggression And Spiritual WellBeing Among The University Students In Jordan. European Scientific Journal, ESJ, 13(2), 269. https://doi.org/10.19044/esj.2017.v13n2p269

Altunbay, M. (2018). Using Literature in Bibliotheraphy: Biography Sampling. Journal of Education and Training Studies, 6(11), 201. https://doi.org/10.11114/jets.v6i11.3593
Aminah, A. N. (2019). Kelebihan kapasitas rutan dan lapas di Jabar capai 52 persen. Republika Online, p. 1. Retrieved from https://nasional.republika.co.id/berita/pubhiq 384/kelebihan-kapasitas-rutan-dan-lapas-dijabar-capai-52-persen

Andersson, G. (2009). Using the Internet to Provide Cognitive Behaviour Therapy. Behaviour Research and Therapy, 47(3), 175180. https://doi.org/10.1016/j.brat.2009.01.010

Apiep, A. (2016). Peningkatan Kesehatan Mental Melalui Pembinaan Akhlaq ( Analisis Pemikiran Al-Ghazali). Jurnal Ilmiah Pendidikan, 10(2), 92-103.

Bjarnadottir, R. I. (2016). Assessment and Documentation of Sexual Orientation and Gender Identity in Home Healthcare. Columbia University. Retrieved from https://search.proquest.com/publichealth/doc view/1835085424/fulltextPDF/4663FF75F27 A4E5DPQ/16? accountid $=190514$

Bruneau, L., \& Pehrsson, D. E. (2014). The Process of Therapeutic Reading: Opening Doors for Counselor Development. Journal of Creativity in Mental Health, 9(3), 346-365. https://doi.org/10.1080/15401383.2014.8928 64

Chew Sim Chee, Amelia Mohd Noor, \& Aslina 
Faletehan Health Journal, 7 (2) (2020) 104-112

www. journal.Ippm-stikesfa.ac.id/ojs/index.php/FHJ

ISSN 2088-673X | 2597-8667

Ahmad. (2013). Empathy and Spirituality: Is There a Gay Advantage? International Journal of Psychology and Behavioral Sciences, $\quad 3(1), \quad 18-22$. https://doi.org/10.5923/j.ijpbs.20130301.03

Cohen, L. J. (1988). Bibliotherapy. The Right Book at The Right Time. Journal of Psychosocial Nursing and Mental Health Services.

Corrigan, P. W., Larson, J. E., Julie, A. E., Ae, H., Matthews, A., Sachi, A. E., ... O'shaughnessy, J. (2009). What Lessons Do Coming Out as Gay Men or Lesbians Have For People Stigmatized by Mental Illness? Community Ment Health Journal, 45, 366374. https://doi.org/10.1007/s10597-0099187-6

Dadfar, M., Bahrami, F., Noghabi, F. S., \& Askari, M. (2016). Relationship Between Religious Spiritual Well-Being and Death Anxiety in Iranian Elders. International Journal of Medical Research \& Health Sciences, 5, 283287. Retrieved from www.ijmrhs.com

Dewi, I. P., \& Widiyanti, A. T. (2018). Qur'anic Therapy (Islamic Bibliotherapy) to Improve Religious Coping in Hemodialysis Patient. Media Keperawatan Indonesia, 1(3), 12. https://doi.org/10.26714/mki.1.3.2018.12-17

Fitriyani, \& Dewi, I. P. (2017). Pengaruh Qur'anic Therapy (Biblioterapi versi Islam) terhadap tingkat kecemasan pada ibu pre operasi dengan sectio caesarea di Ruang Zaitun III RSUD Al Ihsan Provinsi Jawa Barat. Jurnal Ilmu Kesehatan, 11(1), 21-34.

Frieswijk, N., Steverink, N., Buunk, B. P., \& Slaets, J. P. J. (2006). The effectiveness of a bibliotherapy in increasing the selfmanagement ability of slightly to moderately frail older people. Patient Education and Counseling. https://doi.org/10.1016/j.pec.2005.03.011

Gualano, M. R., Bert, F., Martorana, M., Voglino, G., Andriolo, V., Thomas, R., ... Siliquini, R. (2017). The long-term effects of bibliotherapy in depression treatment: Systematic review of randomized clinical trials. Clinical Psychology Review. https://doi.org/10.1016/j.cpr.2017.09.006

Gunawati Sandi., \& Abdul Idawati (2017). Hubungan Lamanya Masa Tahanan Dengan Perilaku Seksual Narapidana Narkoba Di Lembaga Pemasyarakatan. Jurnal Keperawatan, 11(1),21-26.
Gymnastiar, A. (2018). Membangun Pribadi Shalih dan Menshalihkan. Bandung: Emqies Publishing.

Inggriane. (2016). Qur'anic Therapy (1st ed.). Bandung: STIKes Aisyiyah.

Kusuma, P. A. (2012). Konflik diri dan persepsi homoseksual (Lesbian) terhadap nilai-nilai spiritual, 1-18. Universitas Muhammadiyah Surakarta.

Liu, E., Chen, W., Li, Y., Wang, C., Mok, T., \& Huang, H. (2009). Exploring the efficacy of cognitive bibliotherapy and a potential mechanism of change in the treatment of depressive symptoms among the Chinese: A randomized controlled trial. Cognitive Therapy and Research, 33, 449-461.

Lestari, Sukma.,Evi,Martha. (2012). Faktor-Faktor Yang Berhubungan dengan Perilaku Seksual Warga Binaan Pemasyarakatan Wanita di Rumah Tahanan Klas IIa Jakarta Timur. FKM-UI

Pandya, S. P. (2018). Spirituality for mental health and well-being of adult refugees in Europe. Journal of Immigrant and Minority Health, 20(6), 1396-1403. https://doi.org/10.1007/s10903-018-0717-6

Pardini, J., Scogin, F., Schriver, J., Domino, M., Wilson, D., \& LaRocca, M. (2014). Efficacy and Process of Cognitive Bibliotherapy for The Treatment of Depression in Jail and Prison Inmates. Psychological Services, 11(2), 141-152. https://doi.org/10.1037/a0033378

Purvis, A. (2017). ScholarWorks Discrimination, Coming-Out, and Self-Esteem as Predictors of Depression and Anxiety in the Lesbian Community. Walden University. Retrieved from

http://scholarworks.waldenu.edu/dissertations

Shafi, H., Bashir, N., Yousuf, U., Parveen, S., \& Akhter, K. (2016). Relationship between spiritual well-being, life satisfaction and depression: A Study of middle aged people, $3(2)$.

Sugiyarto. (2019). Banyak napi di lapas dan rutan di Jabar jadi homo dan lesbi. Tribun News, p. 1. Retrieved from https://www.tribunnews.com/regional/2019/0 7/09/banyak-napi-di-lapas-dan-rutan-dijabar-jadi-homo-dan-lesbi?page=all

Sugiyono. (2013). Cara mudah menyusun : Skripsi, tesis dan disertasi. (A. Nuryanto, Ed.). 
Bandung: Alfabeta.

Tiah \& Herdiana, D. (2019). Lapas perempuan kelas II Arcamanik Sukamiskin gelar halalbihalal. Tribun News, p. 1. Retrieved from

https://jabar.tribunnews.com/2019/06/15/lapa s-perempuan-kelas-ii-arcamanik-sukamiskin- gelar-halalbihalal-warga-binaan-ceria-danbernyanyi

Van Lankveld, J. J. D. M. (1998). Bibliotherapy in The Treatment of Sexual Dysfunctions: A Meta-Analysis. Journal of Consulting and Clinical Psychology. https://doi.org/10.1037/0022-006X.66.4.702 